\title{
Coyote and bobcat responses to integrated ranch manage- ment practices in south Texas
}

\author{
LISA C. BRADLEY AND DANIEL B. FAGRE
}

\section{Abstract}

Predator use of La Copita Research Area, a 1,093-ha ranch in south Texas, was determined from 2,037 telemetry locations of 11 coyotes and 5 bobcats and numerous sightings of uncollared predators from May 1985 through September 1986. Predator home ranges were small, approximately $3 \mathrm{~km}^{2}$ for both species, and densities were high despite intensive management operations and high levels of human activity. Slight avoidance by predators of cattle and the short duration graxing system was indicated. Roads and fencelines did not defer predator home range establishment and were used as travel lanes and hunting areas. Predators with established home ranges were highly mobile and moved between ranches. Thus, on small ranches in south Texas, management practices conducted on 1 ranch will ilkely influence predator use of the neighboring ranches as well.

\section{Key Words: Canis latrans, Felis rufus, wildlife management}

As traditional ranching operations have become less profitable in recent years, many landowners in south Texas have turned to their wildlife resources for additional income through lease hunting of their properties. The abundant native wildlife of south Texas, such as white-tailed deer (Odocoileus virginianus) and northern bobwhite quail (Colinus virginianus), can provide substantial and vital income to ranchers when livestock markets are depressed (Whitson et al. 1977). For this reason, it has become increasingly important that ranch management programs achieve optimal production of both domestic livestock and marketable wildlife. This integration often requires complex planning and intensive ranch management operations.

Integrated ranching systems have been devised to help guide managers toward more holistic management of habitat and range resources (Scifres et al. 1985). The eventual goal is to provide a ranch manager with decision aids which allow him to predict most of the benefits and consequences of implementing a new management plan or changes in an existing management plan. The responses of predator populations to new and changing ranch management practices should be included because predators can directly impact both livestock and marketable wildlife production (Beasom 1974, Kie et al. 1979). Predators also can potentially influence the outcome of habitat management through predation on smaller herbivores such as rodents and lagomorphs which affect vegetative dynamics. Thus, integrated ranch management systems must incorporate an understanding of predator ecology and predator responses to ranch management operations.

The objective of this study was to investigate coyote (Canis latrans) and bobcat (Felis rufus) responses to a variety of ranch management practices, designed for both livestock and marketable wildlife production, on a typical south Texas ranch.

\footnotetext{
At the time of the research, the authors were research assistant, Department of Wildlife and Fisheries Sciences, Texas A\&M University, College Station 77843; and assistant professor, Department of Wildlife and Fisheries Sciences, Texas A\&M University. Current address of the senior author is Department of Range and Wildlife Management, Texas Tech University, Lubbock 79409.

Research was funded by the Texas Agricultural Experiment Station. The authors wish to thank the Texas Agricultural Experiment Station and the La Copita Research Area staff and advisory committee. We also thank D.J. Martin for his invaluable assistance during the course of this study. This manuscript represents contribution number TA 23125 of the Texas Agricultural Experiment Station.

Manuscript accepted 14 March 1988.
}

Study Area

The study was conducted at the La Copita Research Area, a 1,093-ha ranch located in Jim Wells County, Texas. This ranch is operated by the Texas Agricultural Experiment Station specifically to conduct research on integrated ranching systems. According to the 1985 annual license renewal records of the Texas Parks and Wildlife Department, La Copita is fifth in size of the 21 ranches in Jim Wells County that market wildlife through lease hunting and are licensed shooting preserves.

La Copita is located in the transitional zone between the South Texas Plains and Gulf Prairies and Marshes vegetational regions of Texas (Gould 1975). The overall vegetation type is a thornscrub woodland forming a variety of habitat types ranging from dense thickets to relatively open savannah and native grassland. La Copita is typical of most ranches in this region in its vegetative types and habitat diversity.

Common shrub species of $\mathrm{La}$ Copita include honey mesquite (Prosopis glandulosa), brasil (Condalia obovata), huisache (Acacia farnesiana), blackbrush (Acacia rigidula), whitebrush (Aloysia gratissima), Texas persimmon (Diospyros texana), and cactus (Opuntia spp.) (Walsh 1985). Common forb and grass species include common broomweed (Xanthocephalum dracunculoides), sensitivebriar (Shrankia latidens), Indian mallow (Abutilon incarnum), bermuda grass (Cynodon dactylon), purple threeawn (Aristida purpurea), curly mesquitegrass (Hilaria belangeri), buffelgrass (Cenchrus ciliaris), and bristlegrasses (Setaria spp.) (Walsh 1985).

The climate of this region is warm and humid. Average daily temperature is $30.5^{\circ} \mathrm{C}$ during the summer and $12.2^{\circ} \mathrm{C}$ during the winter. Mean annual rainfall is $67.7 \mathrm{~cm}, 70 \%$ of which falls from April through September, and average daily humidity is 65\% (Soil Conservation Service 1979).

The topography of La Copita is relatively flat with slopes from $0-5 \%$. The mean elevation is $83.8 \mathrm{~m}$. Appoximately $69 \%$ of the ranch is composed of upland range sites associated primarily with sandy loam and gray sandy loam soils. La Copita's drainage areas are claypan prairie and clay loam range sites (Soil Conservation Service 1979).

When this study was initiated in November 1984, the perimeter of La Copita was fenced by $16.5 \mathrm{~km}$ of barbed wire fence (Fig. 1). One 57-ha hay pasture and one 168-ha pasture that was chained in 1978 were the only improved areas on the ranch; the remainder was unimproved native range. Thirty kilometers of dirt road (approximately $3 \mathrm{~m}$ wide) criss-crossed the ranch. Approximately $4.5 \mathrm{~km}$ of these roads were pipeline right-of-ways. Four cleared sites of 0.5 to 1 ha each, formerly the locations of oil drilling rigs, were present on the ranch. A short duration grazing system on the north half of the ranch, constructed December 1984 through February 1985, added $18 \mathrm{~km}$ of interior electric fence and 52 gates. A 2-pasture system on the south half of the ranch added $2.2 \mathrm{~km}$ of electric fence and 8 gates. All interior fences were smooth wire, 3-strand, and approximately $1 \mathrm{~m}$ high. Fence rows were approximately $3 \mathrm{~m}$ wide and were cleared of brush. Two mobile homes, a large storage shed, and a barn were the only buildings on the ranch when the study began. During the study, cattle working pens, a manager's home, an office building/laboratory, and a bunkhouse were constructed.

During this study, La Copita supported a cow-calf operation of 


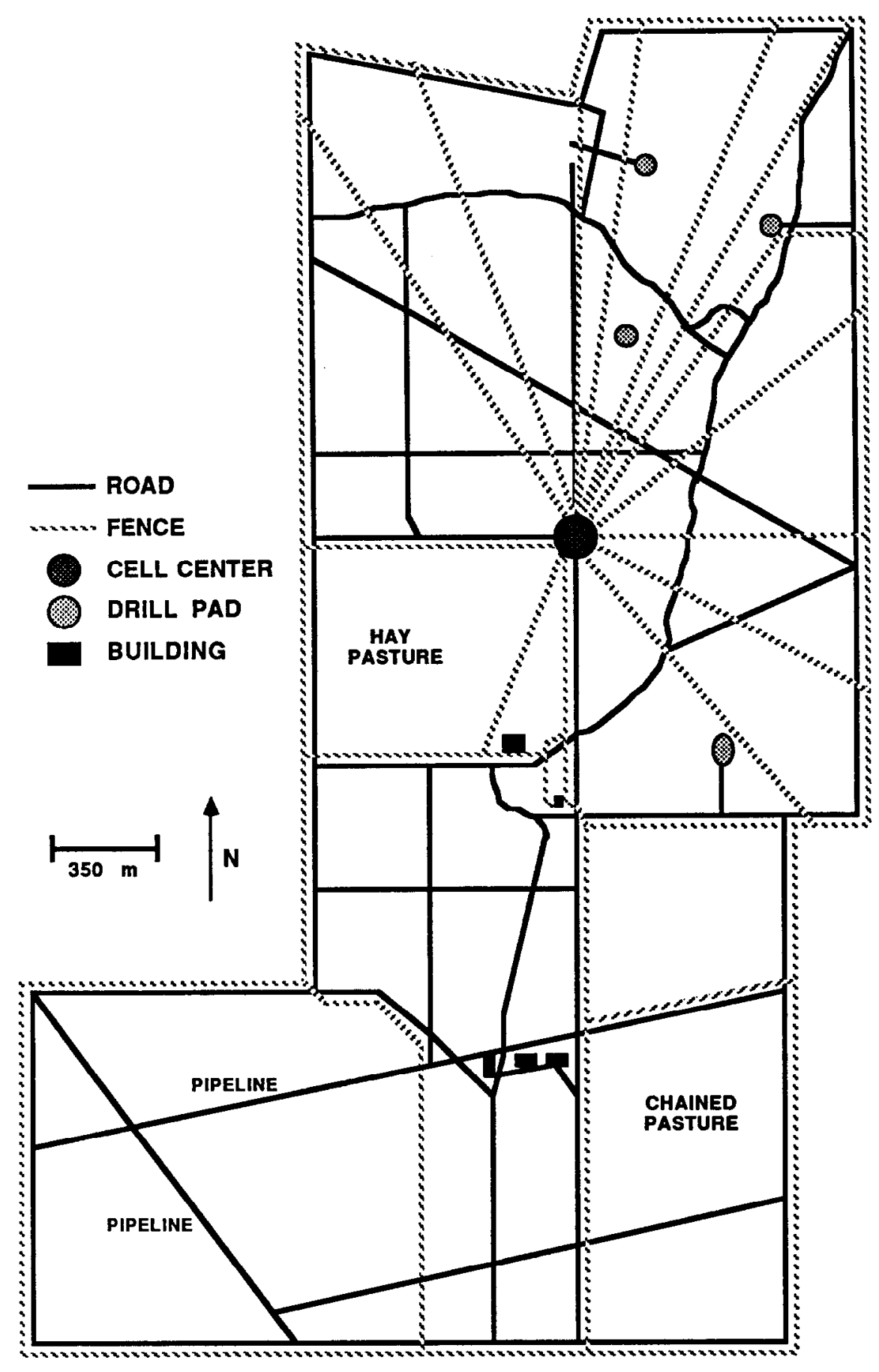

Fig. 1. La Copita Research Area, south Texas.

140 heifers. One hundred head were allocated to the 551-ha, 12pasture short duration grazing system. Pastures of the short duration grazing system ranged from 38 to 65 ha in size. The remaining 40 head were allocated to the 353 ha, 2-pasture deferred rotation grazing system.

\section{Methods}

Coyotes and bobcats were captured with \#3 and \#4 leghold traps with offset jaws and with $\# 3$ padded leghold traps. Tranquilizer tabs (Balser 1965, Linhart et al. 1981) containing $250 \mathrm{mg}$ acepromazine maleate were attached to the jaws of unpadded traps to minimize injury to the captured animals. Captured coyotes and bobcats were sedated with $1.25 \mathrm{cc}$ of ketamine hydrochloride. Each animal was fitted with a radio collar and numbered metal ear tag, held in a cage until recovered from the effects of the sedative, and released at the capture site.

Radio tracking data were collected from April 1985 through September 1986. Radio tracking was conducted from a truck with a mounted antenna system. Animal locations were determined by triangulation from at least 2 of any of 79 permanent tracking stations. Mean size of all error polygons was $0.16 \mathrm{ha}$, indicating a high degree of accuracy in the system. Animals were located once every 4 hours during twice-monthly 72-hour tracking sessions from April 1985 through September 1985. From October 1985 through 
September 1986, animals were located as many times as possible during alternating 6-hour shifts over a 48-hour period, 2 to 4 times per month. Aerial tracking searches were conducted in January, February, and September 1986 for radio signals which could no longer be received on La Copita.

Home range sizes were calculated using the minimum-convex polygon method (Mohr 1947). The outer 5\% of the radio locations for each individual were excluded from the home range calculation to reduce the effect of outlying locations caused by occasional short-term excursions or "sallies" (Burt 1943). Home range sizes were compared by analysis of variance.

Eight habitat types were identified on La Copita and the surrounding area based on aerial photo interpretation. These were: agricultural field, regrown clearing, motty savannah, motty brushland, thicket, ramadero (dense brush bordering an intermittent stream), ramadero park (ramadero with open understory), and laguna (a low area where water collects following heavy rain). Habitat types are described in greater detail in Bradley and Fagre (in review). Habitat use was compared to availability within home ranges, and preference or avoidance of particular habitat types was determined by the family confidence interval method of Neu et al. (1974). Also, habitat composition of home range boundaries was compared to the habitat composition within the home range.

Predator use of roads and fencelines was determined by observing the proportion of radio locations occurring within $20 \mathrm{~m}$ of a road or fence (designated as the "road/ fence influence area") and comparing this value to the proportion of "road/fence influence area" within the home range. Results were compared by Chisquare analysis.

Individual predator responses to the short duration grazing system were examined by comparing the proportion of predator locations within the grazing system to the spatial proportion of the system within the home range.

Individual predator responses to the presence of cattle on the short duration grazing system within the predator's home range were determined by comparing the number of radio locations for which the predator and the cattle were located in the same pasture to the expected number based on the spatial proportion of the pasture within the home range.

Predator activity patterns were determined by calculating the mean movement rate for each hour of the day. The mean movement rate/hour was determined by dividing the distance moved between successive locations by the time interval between those locations. Locations obtained less than $\mathbf{6}$ hours apart were considered successive. The mean time interval between successive fixes was 2.4 hours.

Sixty-eight hectares of the short duration grazing system and 64 ha of the deferred rotation system were aerially sprayed 13 May 1986 with herbicides at the rate of $1.1 \mathrm{~kg} / \mathrm{ha}(1 \mathrm{lb} / \mathrm{acre})$. Various combinations of 5 different herbicides were applied in swaths. Predator response to brush treatments was determined based on 3.5 months of pre-treatment tracking data (6 February-12 May) and 3.5 months of post-treatment tracking data (14 May-28 August). Response was analyzed by comparing predator use of the treated habitat to its availability within the home range. Preference or avoidance of the treated areas was determined by the family confidence interval method of Neu et al. (1974).

\section{Results and Discussion}

\section{General Ecology}

Six male coyotes, 6 female coyotes, 3 male bobcats, and 4 female bobcats were captured on La Copita in 1,424 trap nights ( 1 predator $/ 75$ trap nights, 1 predator $/ 0.58 \mathrm{~km}^{2}$ ). The relatively high number of predators captured per square kilometer may be attributed primarily to the high density of coyotes and bobcats in this region (Andelt 1985, Knowlton et al. 1986). Coyote densities at La Copita may approach 1.0-1.3 coyotes $/ \mathrm{km}^{2}$ (Bradley and Fagre, in review).
Eleven coyotes and 5 bobcats were radio collared. Sufficient data were obtained to determine home ranges for 10 of these animals. Mean home range sizes were $3.07 \mathrm{~km}^{2}$ for 4 male coyotes, $3.01 \mathrm{~km}^{2}$ for 2 female coyotes, and $3.46 \mathrm{~km}^{2}$ for 3 male bobcats. One female bobcat had a home range size of $1.16 \mathrm{~km}^{2}$. Male and female coyote home range sizes were not significantly $(P>0.05)$ different.

The home range sizes determined in this study are among the smallest reported in the literature. Such small home range sizes are probably a function of very high predator densities made possible by an abundance of food resources and suitable habitat (Andelt 1985).

Of the 16 predators radio-collared, 4 were classified as transients, 7 as dispersers, and 5 as residents (Bradley and Fagre, in review). The high proportion of transient and dispersing individuals on La Copita seemed to be compensated for by immigration and/or reproduction, thus maintaining a high predator density on the ranch.

Due to small sample size, intraspecific home range overlap of the collared predators appeared to be minimal. However, sightings of uncollared predators within the home ranges of collared predators indicated that intraspecific home range overlap probably was common. Interspecific home range overlap was extensive on La Copita. There was no indication of interspecific spatial or temporal avoidance by the 2 species (Bradley and Fagre, in review).

Habitat use analyses indicated that coyotes preferred motty brushland habitat and avoided agricultural fields and ramadero parks. Bobcats showed a strong preference for thicket and ramadero habitats and appeared to require these habitat types for home range establishment. Bobcats avoided open habitat types such as agricultural fields and savannah. Ramadero habitats appeared to function as dispersal corridors for both coyotes and bobcats (Bradley and Fagre, in review).

Male and female coyotes and bobcats all exhibited generally crepuscular activity patterns. Predator activity was recorded, however, at all times of the day and night (Fig. 2).

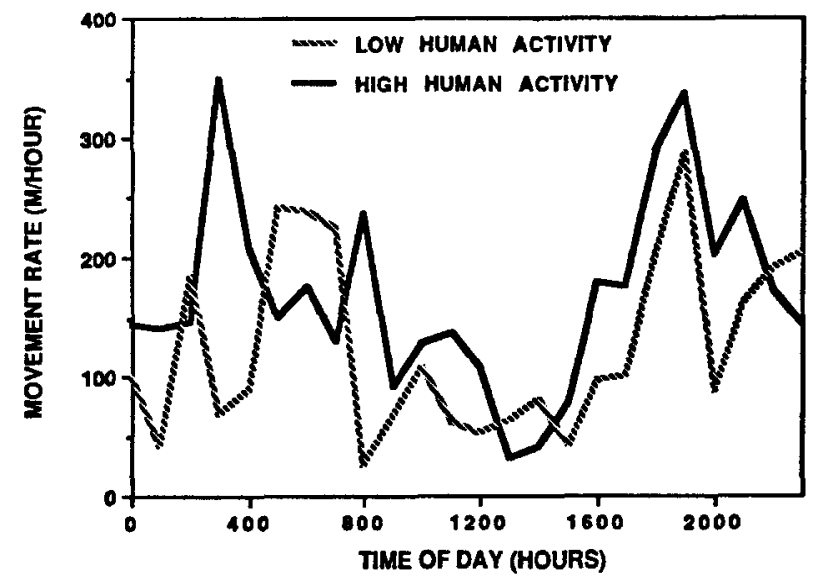

Fig. 2. Comparison of the daily activity patterns of predators exposed to high $(\mathrm{N}=4)$ and low $(\mathrm{N}=6)$ levels of human activity.

\section{Response to Ranching Practices \\ Roads and Fences}

It has been observed that coyotes may use physical structures such as roads and fences as home range boundaries (Hibler 1977). In this study, one adult male bobcat utilized a paved county road with regular vehicular traffic as its southern home range boundary $(1,900 \mathrm{~m}, 28 \%$ of the total boundary). However, this animal later shifted its home range to include this road within its home range boundaries. The bobcat regularly crossed the road after this shift occurred. Portions of 2 other predator home ranges appeared to border roads. Overall, however, only $6 \%(4.15 \mathrm{~km}$ of $68.85 \mathrm{~km})$ of 10 predator's home range boundaries corresponded with roads.

None of the predators in this study utilized the extensive fence- 
line network of the short duration grazing system as home range boundaries. These fencelines, however, had only been in place for 18 months when the study was terminated. It has been suggested that predator home range boundaries may be relatively permanent and are subsequently used by a series of different predators moving into the area over time. The existence of such a land tenure system has been supported for both coyotes and bobcats (Major 1983, Bailey 1974). Therefore, social factors may delay the shift of home range boundaries in response to new structural components within the home range.

Habitat types along home range boundaries differed $(P<.0 .05)$ from habitat composition within the home range. In general, predator home ranges bordered large agricultural fields and regrown clearings, areas which were avoided by predators within their home range. This trend was evident for both coyotes and bobcats. Thus, large areas of cleared land appeared to negatively influence predator movements and home range establishment.

Predator locations within the "road/ fence influence areas" indicated bobcats used roads and fencelines within their home range significantly $(P<0.01)$ more than expected (Tables 1,2$)$. Reports of bobcat sightings on the ranch have confirmed that the cats often hunt from the roadsides and occasionally will lie down on a road. Several other researchers have noted the extensive use of roads and right-of-ways by bobcats for hunting (Shiflet 1984, Kitchings and Story 1978, Hall and Newsom 1976). Coyotes used roads and fencelines to a lesser degree than available within their home range $(P<0.01)$ (Tables 1,2$)$. However, coyotes were frequently sighted

Table 1. Use of roads by coyotes and bobcats as determined by the number of radio locations within a $\mathbf{4 0} \mathrm{m}$ wide "road infuence area" compared to the proportion of this area within the home range.

\begin{tabular}{lcccc}
\hline \hline Species & ID\# & $\begin{array}{c}\text { Road influence } \\
\text { area } \\
\text { \% of home } \\
\text { range) }\end{array}$ & $\begin{array}{c}\text { Expected } \\
\text { number of } \\
\text { locations }\end{array}$ & $\begin{array}{c}\text { Observed } \\
\text { number of } \\
\text { locations }\end{array}$ \\
\hline Coyote & 1060 & 8.6 & 11.6 & 1 \\
& 1262 & 6.7 & 4.0 & 0 \\
& 1540 & 11.5 & 8.9 & 2 \\
& 0746 & 14.7 & 29.4 & 14 \\
& 0700 & 5.7 & 19.1 & 11 \\
& & & & Chi-square $=13.28$, \\
& & & & $P<0.01$ \\
Bobcat & 1522 & 13.1 & 31.0 & 24 \\
& 0722 & 10.2 & 10.7 & 12 \\
& 1553 & 10.9 & 24.6 & 35 \\
& $1642(1)$ & 12.4 & 24.2 & 33 \\
& $1642(2)$ & 6.0 & 11.3 & 19 \\
& & & & Chi-square $=14.58$, \\
& & & & $P<0.01$ \\
\hline
\end{tabular}

on the roads, and coyote tracks revealed that coyotes regularly traveled down roads and fencelines. Therefore, some use of roads and fencelines by coyotes did occur. It should be noted that the occurrence of roads and fences within the home range was similar for coyotes and bobcats. Mean "road influence area" was $9.4 \%$ of coyote home ranges and $10.5 \%$ of bobcat home ranges; mean "fence influence area" was 9.7\% of coyote home ranges and $6.5 \%$ of bobcat home ranges. Thus, it appeared that the presence of roads and fences did not limit predator home range establishment or cause shifts in home range boundaries, but roads and fencelines did provide important travel lanes and hunting areas for the local predators.

The fences of the short duration grazing system apparently had no effect or a slight negative effect on the movements of individual predators within their home ranges. Three of the 5 coyotes that occupied home ranges overlapping this grazing system used that portion of the home range less than expected based on its availabil-
Table 2. Use of fences by coyotes and bobcats as determined by the number of radio locations within a $40 \mathrm{~m}$ wide "fence influence area" compared to the proportion of this area within the home range.

\begin{tabular}{lcccc}
\hline Species & ID\# & $\begin{array}{c}\text { Fence influence } \\
\text { area } \\
\text { (\% of home } \\
\text { range) }\end{array}$ & $\begin{array}{c}\text { Expected } \\
\text { number of } \\
\text { locations }\end{array}$ & $\begin{array}{c}\text { Observed } \\
\text { number of } \\
\text { locations }\end{array}$ \\
\hline Coyote & 1060 & 7.5 & 10.1 & 0 \\
& 1262 & 5.9 & 3.5 & 3 \\
& 1540 & 16.7 & 12.9 & 4 \\
& 0746 & 16.7 & 33.4 & 28 \\
& 0700 & 1.7 & 5.7 & 0 \\
& & & & Chi-square $=22.87$, \\
Bobcat & 1522 & 13.8 & 32.7 & < \\
& 0722 & 11.7 & 12.3 & 35 \\
& 1553 & 2.1 & 4.8 & 16 \\
& $1642(1)$ & 3.4 & 6.6 & 7 \\
& $1642(2)$ & 1.6 & 3.0 & 15 \\
& & & & Chi-square $=34.13$, \\
& & & & $P<0.01$ \\
\hline
\end{tabular}

ity. Two coyotes and 2 bobcats used the short duration grazing system in proportion to its occurrence within their home ranges. On 1 occasion a bobcat was sighted drinking from the water trough in the center of this grazing system.

\section{Cattle and Human Activity}

On 369 occasions, cattle were located within the home range of a predator while the predator was being tracked. Overall, collared predators and cattle were located within the same pasture of the short duration grazing system for only $9.5 \%$ of these locations, although cattle-occupied pastures comprised $12 \%$ of predator home ranges. Thus, a slight avoidance of cattle by the collared predators was indicated. Individual predator responses are presented in Table 3.

Table 3. Observed proportion of predator locations occurring within a cattle-occupied pasture of the short duration graxing system compared to the proportion of these pastures within the predator home range (i.e., expected proportion of locations).

\begin{tabular}{lccc}
\hline \hline Species & ID \# & $\begin{array}{c}\text { Proportion of cattle- } \\
\text { occupied pastures } \\
\text { within the } \\
\text { home range }\end{array}$ & $\begin{array}{c}\text { Proportion of } \\
\text { predator } \\
\text { locations with } \\
\text { cattle }\end{array}$ \\
\hline Coyote & 1060 & $2-19 \%(\bar{x}=11 \%)$ & $0 \%$ \\
& 1262 & $25-47 \%(\bar{x}=33 \%)$ & $100 \%$ \\
& 1540 & $2-14 \%(\bar{x}=8 \%)$ & $9 \%$ \\
Bobcat & 0746 & $2-24 \%(\bar{x}=8 \%)$ & $5 \%$ \\
& 0722 & $5-18 \%(\bar{x}=13 \%)$ & $9 \%$ \\
\hline
\end{tabular}

Four of the 10 predators in this study occupied home ranges that contained paved county roads, human dwellings, construction sites, or other areas of frequent human use. Activity patterns of these 4 predators were crepuscular, similar to the activity patterns of the 6 predators subjected to less human disturbance (Fig. 2), indicating no temporal shift in activity patterns to avoid human activity. One adult male bobcat was located within $250 \mathrm{~m}$ of a construction site on the ranch on 7 occasions, and 3 of these locations were during daylight hours while construction activities were occurring. Coyote scats were occasionally found in partially constructed buildings and on the doorsteps of occupied trailers. Thus, it appeared that the predators on La Copita had a very high tolerance to human activity and disturbance. Although predators 
exposed to high levels of human activity apparently had an overall activity level slightly higher than that of predators less exposed to human disturbance (Fig. 2), a $t$-test of the hourly means was not significant $(P>0.10)$. Mean hourly movement rates of predators were highest from December through March (Fig. 3).

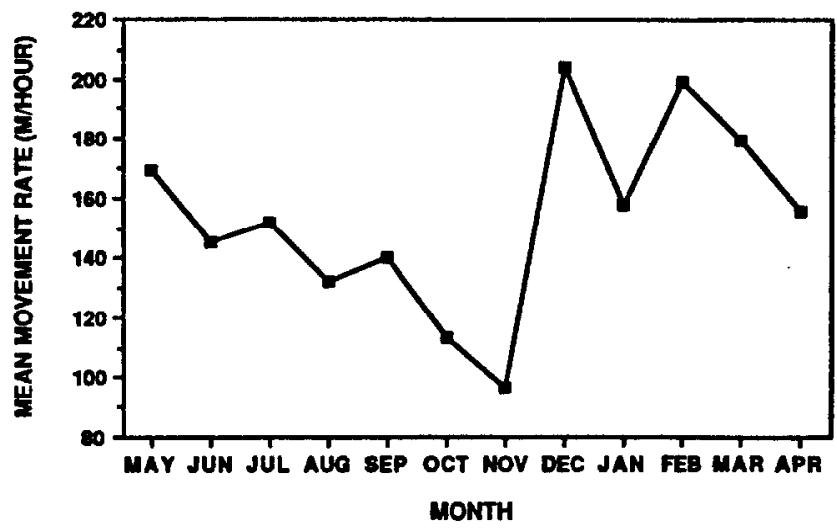

Fig. 3. Mean monthly movement rates of predators $(\mathrm{N}=10)$ at the La Copita Research Area.

\section{Brush Treatments}

Defoliation of the brush began within 2 weeks after the application of the herbicides; complete defoliation of the brush and a noticeable increase in grass production occurred within 4 weeks. The structural component of the vegetation (i.e., dead stems and branches forming a canopy) remained relatively unchanged following the treatments. Also, rodent populations, as determined by small mammal trapping results, did not change in the treated areas during this period (Gary Drew, Texas A\&M Univ., pers. comm.).

Portions of 4 collared predator home ranges were aerially sprayed (Fig. 4). Predators did not shift home ranges in response to the treatments. Predator use of the treated areas was as follows: a female bobcat and a male bobcat showed no preference or avoidance $(P>0.05)$ of the treated areas before or after the treatments took place; a female coyote showed no preference or avoidance before the treatments, but seemed to prefer $(P<0.05)$ the treated areas during the post-treatment period; a male bobcat apparently preferred $(P<0.05)$ the treated areas before the treatments, but did not prefer or avoid these areas during the post-treatment period (Table 4).

Table 4. Coyote and bobcat use of treated habitat before and after the treatments on La Copita Research Area, 1985-1986. Preference $(P<0.05)$ indicated by (+) (Neu et al. 1974).

\begin{tabular}{|c|c|c|c|c|c|}
\hline \multirow[b]{2}{*}{ Species } & \multirow[b]{2}{*}{ Sex } & \multirow[b]{2}{*}{ ID \# } & \multirow{2}{*}{$\begin{array}{c}\% \text { home } \\
\text { range affected }\end{array}$} & \multicolumn{2}{|c|}{$\%$ of locations } \\
\hline & & & & Pre-trt. & Post-trt. \\
\hline $\begin{array}{l}\text { Bobcat } \\
\text { Bobcat } \\
\text { Coyote } \\
\text { Bobcat }\end{array}$ & $\begin{array}{c}\mathbf{F} \\
\mathbf{M} \\
\mathbf{F} \\
\mathbf{M}\end{array}$ & $\begin{array}{l}1522 \\
1553 \\
0746 \\
1642\end{array}$ & $\begin{array}{r}46 \\
14 \\
16 \\
9\end{array}$ & $\begin{array}{l}46 \\
11 \\
12 \\
24(+)\end{array}$ & $\begin{array}{l}41 \\
12 \\
34(+) \\
9\end{array}$ \\
\hline
\end{tabular}

Coyotes feed almost exclusively on fruits, especially persimmon, during the summer (Short 1979, Meinzer et al. 1975). Texas persimmon was resistant to the herbicides utilized in this study and fruit was readily available to coyotes in the treated areas. Thus, the female coyote's apparent preference for the post-treatment areas may have been a reflection of higher persimmon densities in these areas or improved access to persimmon fruits due to defoliation of other species, although these hypotheses were not tested.

The male bobcat's apparent preference for the pre-treatment areas is probably an artifact of this bobcat's home range shift. During the 7 months of pre- and post-treatment monitoring, this

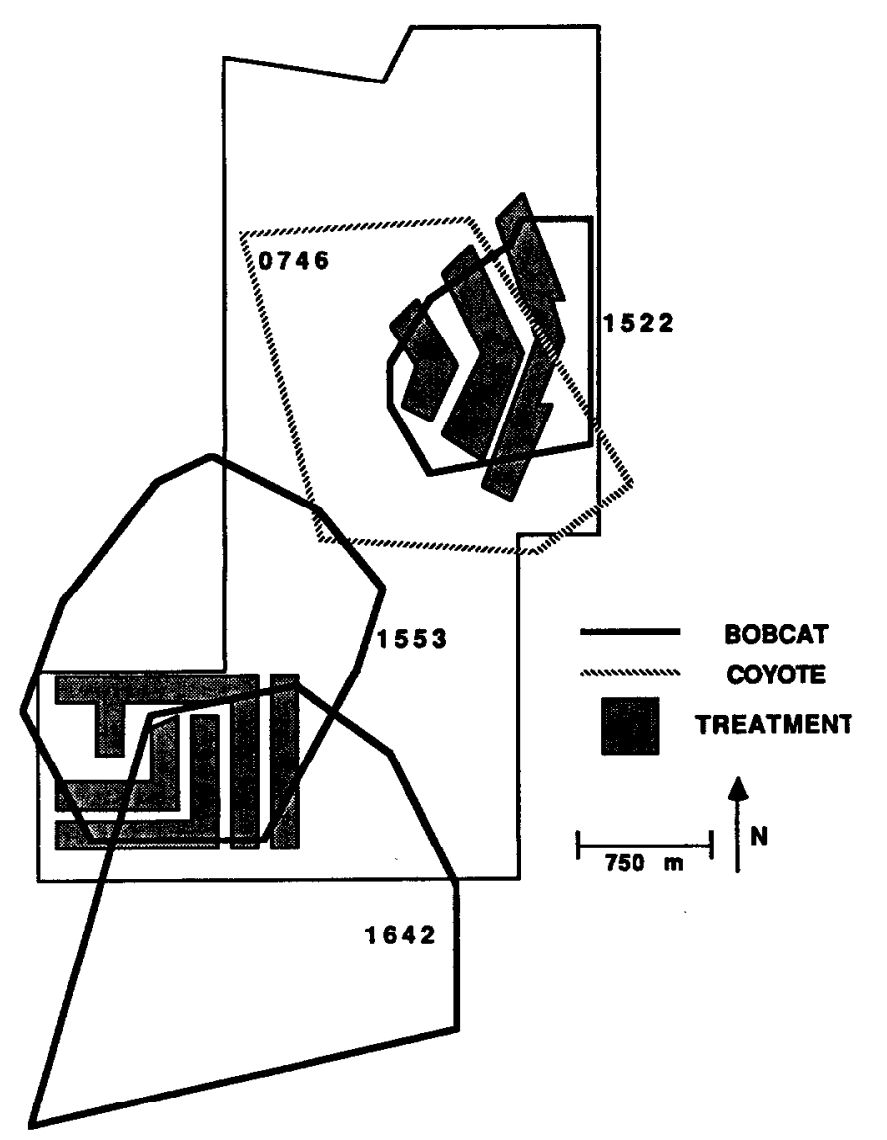

Fig. 4. Herbicide treatments at La Copita Research Area and the affected predator home ranges.

animal was in the process of shifting its primary use areas to the south of La Copita. Therefore more locations were on La Copita, and by chance within the treatment areas, before the treatments took place than after.

\section{Predator Density and Use of La Copita}

An average of 5 to 6 radio collared individuals were being tracked on the ranch at one time. However, numerous sightings of uncollared coyotes and bobcats on the ranch indicated that the predator density on La Copita at any one time was much higher than the 5 to 6 radio collared predators. Approximately half of all predator sightings reported during this study were of uncollared predators, and most were within the known home ranges of collared predators. It was clear that the entire predator population on the ranch was not monitored and the trapping and radio tracking results alone underestimated predator use of La Copita.

Of the 16 radio collared predators, 5 individuals dispersed from the area before sufficient data were obtained to determine a home range. Of the 11 home ranges determined, an average of $65 \%$ of the home range area and $60 \%$ of the radio locations were on La Copita. Thus, even resident predators did not confine their movements to the ranch. In fact, only 1 individual's home range was completely within La Copita's borders. It appeared that La Copita and the surrounding ranches shared the same predators and they freely moved between these areas. Habitat changes on $\mathrm{La}$ Copita favoring predators may lead to a more intensive use of La Copita relative to the surrounding areas and an increase in the local predator densities.

\section{Conclusions}

Intensive ranch management practices at the La Copita Research 
Area may have negatively influenced predator use of the short duration grazing system and cattle-occupied pastures of that system. However, predator densities and predator use of the ranch remained high, there were no apparent short-term changes after herbicide treatment, and new roads and fencelines may have provided additional travel lanes and hunting areas for the local predator population.

Given the small average size of the ranches which market wildlife in south Texas, and the mobility of predators in this region, ranch management practices undertaken by a rancher also may have potential impacts on nearby ranches. Thus, ranchers in this region are faced with the challenging goal of integrating their ranching operations not only for livestock and wildlife, but with the management plans of neighboring ranches as well.

Additional studies addressing long-term predator responses to ranch management practices are suggested. These studies should include prey density responses, predator food habit responses, and predator time/energy budget analyses.

\section{Literature Cited}

Andelt, W.F. 1985. Behavioral ecology of coyotes in south Texas. Wildl. Monogr. 94.

Bailey, T.N. 1974. Social organization in a bobcat population. J. Wildl. Manage. 38:435-446.

Balser, D.S. 1965. Tranquilizer tabs for capturing wild carnivores. J. Wildl. Manage. 29:438-442.

Beasom, S.L. 1974. Relationships between predator removal and whitetailed deer net productivity. J. Wildl. Manage. 38:854-859.

Bradley, L.C., and D.B. Fazre. In Review. Patterns of movement and habitat use by coyotes and bobcats in south Texas brushlands. Proc. Annu. Conf. S.E. Ass. Fish and Wildl. Agencies.

Burt, W.H. 1943. Territoriality and home range concepts as applied to mammals. J. Mammal. 24:346-353.

Gould, F.W. 1975. Texas plants, a checklist and ecological summary. Texas Agr. Exp. Sta., Texas A\&M Univ., College Station.

Hall, H.T., and J.D. Newrom. 1976. Summer home ranges and movements of bobcats in bottomland hardwoods of southern Louisiana. Proc. Annu. Conf. S.E. Ass. Fish and Wildl. Agencies 30:427-436.
Hibler, S.J. 1977. Coyote movement patterns with emphasis on home range characteristics. M.S. Thesis, Utah State Univ., Logan.

Kie, J.G., M.W. White, and F.F. Knowiton. 1979. Effects of coyote predation on population dynamics of white-tailed deer. Proc. Welder Wildl. Found. Symp. 1:65-82.

Kitchings, J.T., and J.D. Story. 1978. Preliminary studies of bobcat activity patterns. Proc. Annu. Conf. S.E. Ass. Fish and Wildl. Agencies. 32:53-59.

Knowiton, F.F., L.A. Windberg, and C.E. Wahlgren. 1986. Coyote vulnerability to several management techniques. p. 165-176. In: D.B. Fagre, ed., Proc. 7th Great Plains Wildl. Damage Control Workshop. Agr. Comm., Texas A\&M Univ., College Station.

Linhart, S.B., G.J. Dasch, and F.J. Turkowakd. 1981. The steel leg-hold trap: techniques for reducing foot injury and increasing selectivity. p. 1560-1578. In: J.A. Chapman and D. Pursley, eds., Worldwide Furbearer Conf. Proc., Vol. III. Frostburg, Maryland.

Major, J.T. 1983. Ecology and interspecific relationships of coyotes, and bobcats, and red foxes in western Maine. PhD Thesis, Univ. of Maine, Orono.

Meinzer, W.P., D.N. Ueckert, and J.T. Flinders. 1975. Foodniche of coyotes in the rolling plains of Texas. J. Range Manage. 28:22-27.

Mohr, C.O. 1947. Table of equivalent populations of North American small mammals. Amer. Midl. Natur. 37:223-249.

Neu, C.W., C.R. Byers, and J.M. Peek. 1974. A technique for analysis of utilization-availability data. J. Wildl. Manage. 38:541-545.

Scifres, C.J., W.T. Hamilton, J.R. Conner, J.M. Inglis, G.A. Rasmussen, R.P. Smith, J.W. Stuth, and T.G. Welch. 1985. Integrated brush management systems for south Texas: Development and implementation. Texas Agr. Exp. Sta., Texas A\&M Univ., College Station.

Shifhet, D.S. 1984. Habitat use, home range, and movements of bobcats in western Montana. Fish and Wildl. Ref. Service, Job Prog. Rep., Res. Proj.

Short, H.L. 1979. Food habits of coyotes in a semidesert grass-shrub habitat. Rocky Mtn. Forest and Range Exp. Sta., Res. Note RM-364.

Soll Conservation Service. 1979. Soil survey of Jim Wells County, Texas. USDA Soil Conserv. Serv.

Walsh, P.B. 1985. Habitat use and population fluctuations of white-tailed deer at La Copita Research Area, Jim Wells County, Texas. M.S. Thesis, Texas A\&M Univ., College Station.

Whitson, R.E., S.L. Beasom, and C.J. Scifres. 1977. Economic evaluation of cattle and white-tailed deer response to aerial spraying of mixed brush. J. Range Manage. 30:214-217. 